\title{
Determinants of Current Account Balance in ASEAN+6
}

\author{
Dewi Purnama $^{1^{*}}$, Budiono ${ }^{2}$, Anhar Fauzan Priyono $^{3}$ \\ ${ }^{123}$ Universitas Padjadjaran, Indonesia,dewi17013@mail.unpad.ac.id \\ 1dewi17013@mail.unpad.ac.id, ${ }^{2}$ budiono2017@unpad.ac.id, ${ }^{3}$ anhar.fauzan.priyono@unpad.ac.id \\ *corresponding author
}

\begin{abstract}
The phenomenon of global current account imbalance has made researchers and policy makers provide more attention on current account issues. This phenomenon is illustrated by the US' current account deficit which continues to increase, while ASEAN+6 reaps a surplus. This study aims to study the factors that affect the aggregate current account in ASEAN+6 that have not been explained by previous studies. Based on the dynamic panel model (GMM) used, it was found that the variables Lagged-current account, ToT, Exchange Rate Stability, and Household Consumption have a significant effect on the aggregate current account in ASEAN+6. On the other hand, the REER and Government Expenditures do not have a significant effect on the ASEAN+6 current account. The benefit of this research is that it can be used for the formulation of current account policies to minimize the government's efforts to overcome a bigger issue: imbalance in balance of payment.
\end{abstract}

Keywords: Current account balance, Generalized Method of Moment, ASEAN+6

\section{Determinan Neraca Transaksi Berjalan di ASEAN+6}

\begin{abstract}
Abstrak
Fenomena ketidakseimbangan transaksi berjalan global telah membuat para peneliti dan pembuat kebijakan memberikan perhatian lebih pada masalah transaksi berjalan. Fenomena ini tergambar dari defisit transaksi berjalan AS yang terus meningkat, sedangkan ASEAN+6 menuai surplus. Penelitian ini bertujuan untuk mempelajari faktor-faktor yang mempengaruhi neraca transaksi berjalan agregat di ASEAN+6 yang belum dijelaskan oleh penelitian-penelitian sebelumnya. Berdasarkan model panel dinamis (GMM) yang digunakan, ditemukan bahwa variabel Lagged-current account, ToT, Exchange Rate Stability, dan Household Consumption berpengaruh signifikan terhadap agregat current account di ASEAN+6. Di sisi lain, REER dan Belanja Pemerintah tidak berpengaruh signifikan terhadap transaksi berjalan ASEAN+6. Manfaat dari penelitian ini adalah dapat digunakan untuk perumusan kebijakan transaksi berjalan untuk meminimalkan upaya pemerintah mengatasi masalah yang lebih besar: ketidakseimbangan neraca pembayaran.
\end{abstract}

Kata kunci: Neraca transaksi berjalan, Generalized Method of Moment, ASEAN+6

\section{INTRODUCTION}

In line with developments of economic activity, economic openness has also had an impact on a country's current account balance. Economic globalization, which according to the International Monetary Fund (2008) refers to the increasing integration of a country's domestic economy into the world economy, has driven the movement of goods, services, capital, and even labor across borders between countries. Income and expenditures arising from these economic activities are recorded in the current account balance which is part of the balance of payments. The current account balance is an important macroeconomic indicator for measuring the performance of the external sector since it shows the economy's competitiveness. Besides, the current account balance assists 
policy makers in formulating macroeconomic policies to ensure a sustainable external position (Uneze\&Ekor, 2012).

The phenomenon of imbalance in the current account has made researchers and policy makers pay more attention to the current account balance issues. Referring to research (Das, 2016), current account imbalances at the global level was found to be increased when the United States and other developed countries experienced continuous current account deficits, while emerging market countries such as China and other countries in Asia were also included in ASEAN+6 countries achieved a larger surplus.

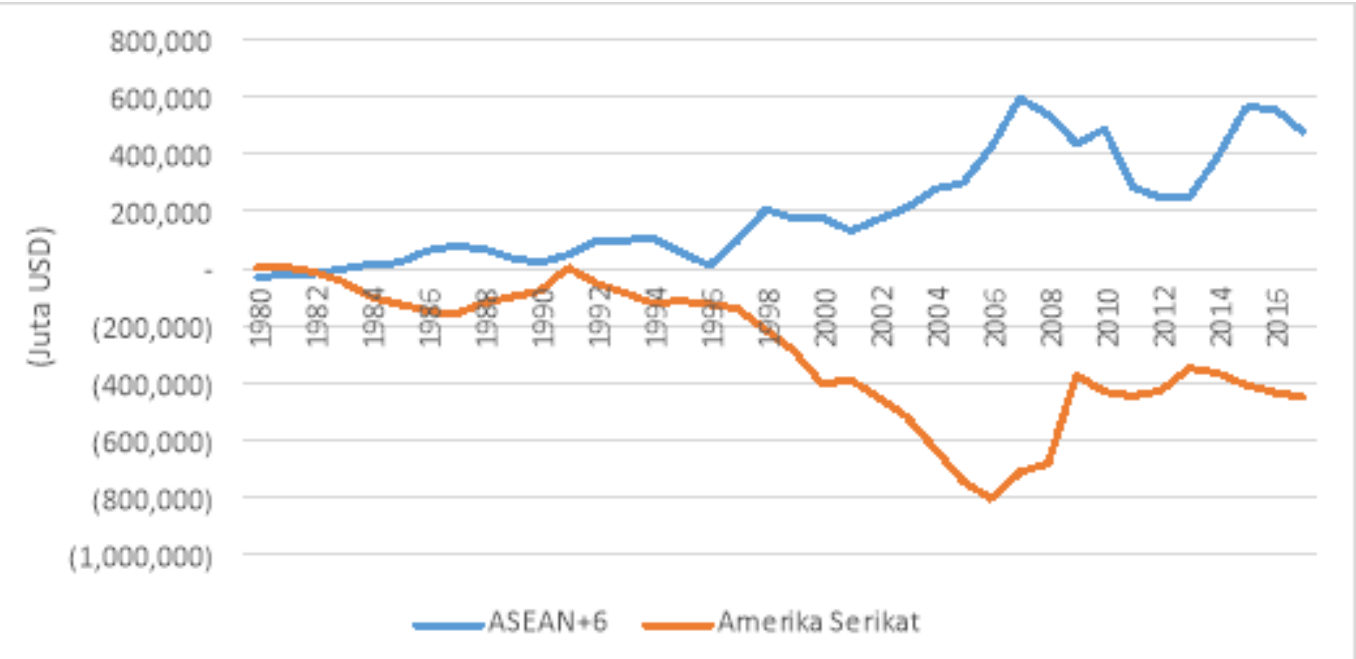

Figure 1. Comparison of ASEAN+6 Current Account Balance and the United States (in Million USD) 1980-2017 (UNCTADstat, 2019)

Figure 1 presents that the current account balance values in 1980 in ASEAN+6 countries and the United States are both near zero. However, in its development there has been a gap, especially since 1997-1998 where the current account deficit in the United States has deepened, while the current account surplus for ASEAN +6 is getting higher. The peak occurred in 2006-2007 where the current account deficit in the United States reaches 805.9 billion USD (-5.7\% of GDP) in 2006. Meanwhile the ASEAN+6 current account surplus in aggregate reaches 594.4 billion USD in 2007 (4.1\% of GDP). In 2009, there is a decrease in current account imbalance (narrowing gap) as the volume and value of global trade shrank sharply. However, in 2010-2011 the current account imbalance increased again. In fact, according to research by Das (2016), China and other Asian tiger countries (South Korea, Malaysia, Singapore, Indonesia, and Thailand) experiences an average current account surplus of $6.4 \%$ of GDP in 2000-2009 which put they are the largest lenders in the world. The increase in the current account balance in the ASEAN+6 region after the financial crisis of 1997-1998 prompted the need for empirical research on the factors that influence the movement of the current account in ASEAN+6. 
ASEAN+6 is a collaboration between 10 ASEAN countries and 6 trading partner countries consisting of China, Japan, South Korea, India, Australia, and New Zealand. The sixteen countries are part of the Regional Comprehensive Economic Partnership (RCEP) free trade agreement. Cited from the Ministry of Trade's website (Ditjenppi, 2018), RCEP has the potential to provide significant opportunities for businesses actors in the East Asia region and create "The World's Largest Trading Bloc" considering that the 16 RCEP participating countries account for almost half of the world's population; contributes about 30 percent of global GDP; creates $28 \%$ of total world trade and $27 \%$ of the world's FDI flows.

Table 1. ASEAN+6 Contributions to the World Economy in 2017

\begin{tabular}{|c|c|c|c|c|c|c|c|c|}
\hline Country & $\begin{array}{c}\text { Population } \\
\text { (million } \\
\text { people) }\end{array}$ & $\%$ & $\begin{array}{c}\text { GDP } \\
\text { (billion } \\
\text { USD) }\end{array}$ & $\%$ & $\begin{array}{c}\text { Trade } \\
\text { (million } \\
\text { USD) }\end{array}$ & $\%$ & $\begin{array}{c}\text { FDI } \\
\text { (Thousa } \\
\text { nd } \\
\text { USD) }\end{array}$ & $\%$ \\
\hline Indonesia & 264.65 & $3.52 \%$ & 1.09 & $1.36 \%$ & 0.40 & $0.88 \%$ & 23.06 & $1.61 \%$ \\
\hline Malaysia & 31.11 & $0.41 \%$ & 0.36 & $0.45 \%$ & 0.43 & $0.94 \%$ & 9.54 & $0.67 \%$ \\
\hline Thailand & 69.21 & $0.92 \%$ & 0.42 & $0.53 \%$ & 0.56 & $1.23 \%$ & 7.64 & $0.53 \%$ \\
\hline Philippines & 105.17 & $1.40 \%$ & 0.30 & $0.38 \%$ & 0.23 & $0.50 \%$ & 9.52 & $0.67 \%$ \\
\hline Singapura & 5.61 & $0.07 \%$ & 0.32 & $0.40 \%$ & 1.08 & $2.37 \%$ & 62.01 & $4.34 \%$ \\
\hline Vietnam & 94.60 & $1.26 \%$ & 0.18 & $0.22 \%$ & 0.45 & $0.99 \%$ & 14.10 & $0.99 \%$ \\
\hline Laos & 6.95 & $0.09 \%$ & 0.01 & $0.01 \%$ & 0.01 & $0.03 \%$ & 0.81 & $0.06 \%$ \\
\hline Cambodia & 16.01 & $0.21 \%$ & 0.02 & $0.02 \%$ & 0.03 & $0.06 \%$ & 2.78 & $0.19 \%$ \\
\hline Myanmar & 53.38 & $0.71 \%$ & 0.08 & $0.10 \%$ & 0.03 & $0.07 \%$ & 4.34 & $0.30 \%$ \\
\hline $\begin{array}{l}\text { Brunei } \\
\text { Darussalam }\end{array}$ & 0.42 & $0.01 \%$ & 0.01 & $0.02 \%$ & 0.01 & $0.02 \%$ & $(0.05)$ & $0.00 \%$ \\
\hline China & $1,386.40$ & $18.46 \%$ & 10.13 & $12.63 \%$ & 4.63 & $10.22 \%$ & 136.32 & $9.53 \%$ \\
\hline Japan & 126.79 & $1.69 \%$ & 6.14 & $7.66 \%$ & 1.68 & $3.71 \%$ & 10.43 & $0.73 \%$ \\
\hline South Korea & 51.47 & $0.69 \%$ & 1.35 & $1.68 \%$ & 1.24 & $2.73 \%$ & 17.05 & $1.19 \%$ \\
\hline Australia & 24.60 & $0.33 \%$ & 1.38 & $1.72 \%$ & 0.56 & $1.23 \%$ & 46.37 & $3.24 \%$ \\
\hline New Zealand & 4.79 & $0.06 \%$ & 0.18 & $0.23 \%$ & 0.11 & $0.24 \%$ & 3.57 & $0.25 \%$ \\
\hline India & $1,338.66$ & $17.82 \%$ & 2.66 & $3.32 \%$ & 1.08 & $2.38 \%$ & 39.92 & $2.79 \%$ \\
\hline ASEAN+6 & $3,579.81$ & $47.66 \%$ & 24.64 & $30.72 \%$ & 12.52 & $27.60 \%$ & 387.42 & $27.10 \%$ \\
\hline World & $7,510.99$ & $100.00 \%$ & 80.21 & $100.00 \%$ & 45.35 & $100.00 \%$ & $1,429.81$ & $\begin{array}{r}100.00 \\
\%\end{array}$ \\
\hline
\end{tabular}

In the last 25 years, the current account balance of ASEAN+6 countries have changed significantly or more precisely after the Asian crisis in 1997, especially in the 2000s period as shown in Figure 2. 


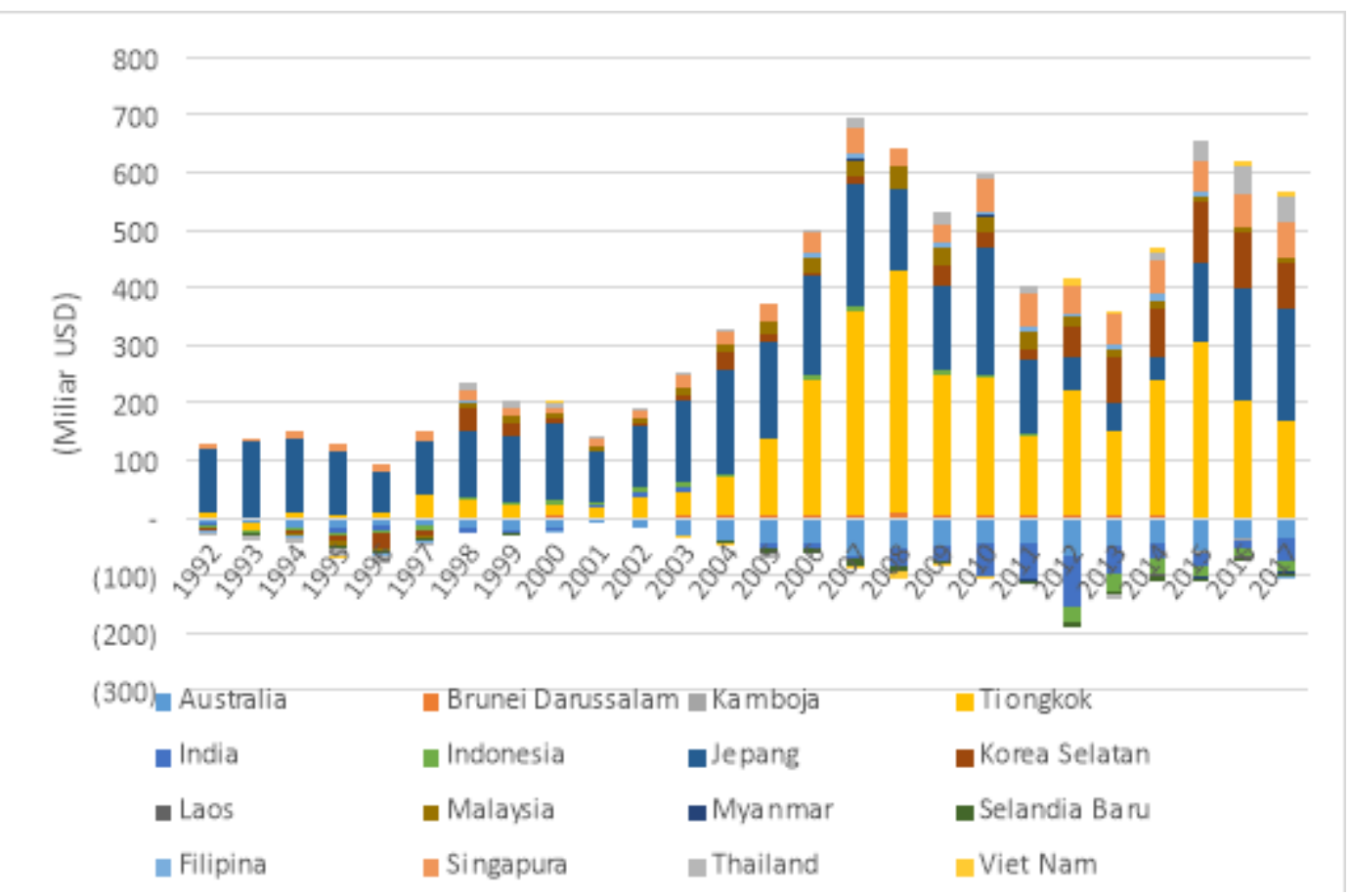

Figure 2. Current Account Balance Developments in ASEAN+6 Countries (in Billion USD)

1992-2017 (UNCTAD stat, 2019)

ASEAN+6 countries experienced dynamics of the current account balance, both in the period before the 1997-1998 crisis and after the 1997-1998 crisis. Among them are Indonesia, Malaysia, Thailand, the Philippines and South Korea. These countries experienced a deficit before the crisis which turned into a surplus after the crisis (1998). In general, the current account balance of ASEAN+6 countries moved dynamically after the Asian crisis, especially since 2000, except for China and the Philippines, which consistently increased their current account surplus. However, the current account balance in its development decreased simultaneously in many ASEAN+6 countries during the global crisis in 2008 (except for China, Brunei and the Philippines which experienced an increase) and in 2012 due to the decline in global commodity prices. During the global crisis in 2008 the prices of various international commodities declined in line with lower demand, such as wheat, corn, crude oil, and copper. The decline in world commodity prices resulted in a significant drop in the value of exports in various countries as a support for the current account balance. In 2008 many countries experienced a decrease in surplus or an increase in the current account deficit due to the decline in world commodity prices. In 2012, the decline in the current account was partly due to lower prices for various commodities and lower external demand. On the other hand, domestic demand has increased, including in the energy sector. As a result, high imports in the oil and gas sector led to a decline in the current account balance, as happened in Indonesia and Japan. 
Towards the end of the research period, especially from 2012-2017, many countries could not make their way out of the current account deficit, such as Indonesia, India, Australia, New Zealand even though the deficits in these countries had decreased. After the crisis, other ASEAN+6 countries gradually improve their current account balance, including Japan, China, and South Korea. In 2013, South Korea succeeded in increasing its current account balance, supported by global demand that began to increase and increased productivity which kept labor costs low. Meanwhile, in 2014 China succeeded in increasing its current account surplus again, supported by its trade balance surplus. In 2015, Japan succeeded in increasing the current account surplus as supported by primary income transactions which recorded an increase in the income of its citizens abroad and high service transactions in its tourism sector.

Current account imbalances at the global level have led many researchers in studies the factors that affect the current account balance. Among them is the research of Das (2016) which took the object of research consisting of groups of developed countries, developing countries and emerging countries. Aristovnik (2008) also conducted a similar study on Western European countries and the former Soviet Union. In addition, Yang (2011) conducted the same research as the objects of emerging countries in Asia. So that this research is expected to contribute by presenting an analysis of the factors that affect the current account balance with a new research object, namely ASEAN+6 countries which have not been done before.

It was stated by (Pilbeam, 2006) regarding three balance of payments approaches consist of an elasticity approach, an absorption approach, and a monetary approach. The elasticity approach and the absorption approach are two models that investigate the impact of exchange rate changes on the current account position of a country. Meanwhile, the monetary approach explains the imbalance of the balance of payments due to an imbalance in the money market. Based on the background condition of the current account balance above, the main problems will be discussed in this study are:

- How does the elasticity approach explain the movement of the current account balance in ASEAN+6 countries and Indonesia?

- How does the monetary approach explain the movement of the current account balance in ASEAN+6 countries and Indonesia?

- How does the absorption approach explain the movement of the current account balance in ASEAN+6 countries and Indonesia?

- The thinking framework in this study departs from the phenomenon of imbalance in the current account at the global level. In the last three decades, the world's current account has doubled from a deficit of $0.46 \%$ in 1980 to a surplus of $0.55 \%$ of world GDP in 2017. However, this condition was followed by an imbalance increase in the current account balance at the global level. The research conducted by Das (2016) found that current account imbalance at the global level experienced an increases when the United States and other developed countries have a continuous current account deficit while 
emerging market countries such as China and other countries in Asia as also included in ASEAN+6 countries achieve an even bigger surplus. The widening gap between the current account surplus of ASEAN+6 (which is dominated by China) and the current account deficit of the United States is reflected in the trade balance of the two countries. Since the 1980s, the US current account deficit has been dominated by the goods account deficit (the difference between exports and imports of goods), while China's current account surplus (as the main driver of ASEAN+6) is dominated by a goods balance surplus. Based on data from the United States Department of Commerce in 2017, it is stated that China is the main importing country for the United States with an import value of USD 505.4 billion (17.4\% of total US imports). This condition makes China the largest contributor to the US trade balance deficit. Considering that the trade balance is part of the current account balance, the condition of the trade balance of the two countries has contributed to an imbalance in the current account at the global level. The increase in the ASEAN+6 region current account balance after the financial crisis of 1997-1998 especially 2000-2017 has prompted the need for empirical research on the factors affecting the movement of the current account in ASEAN+6.

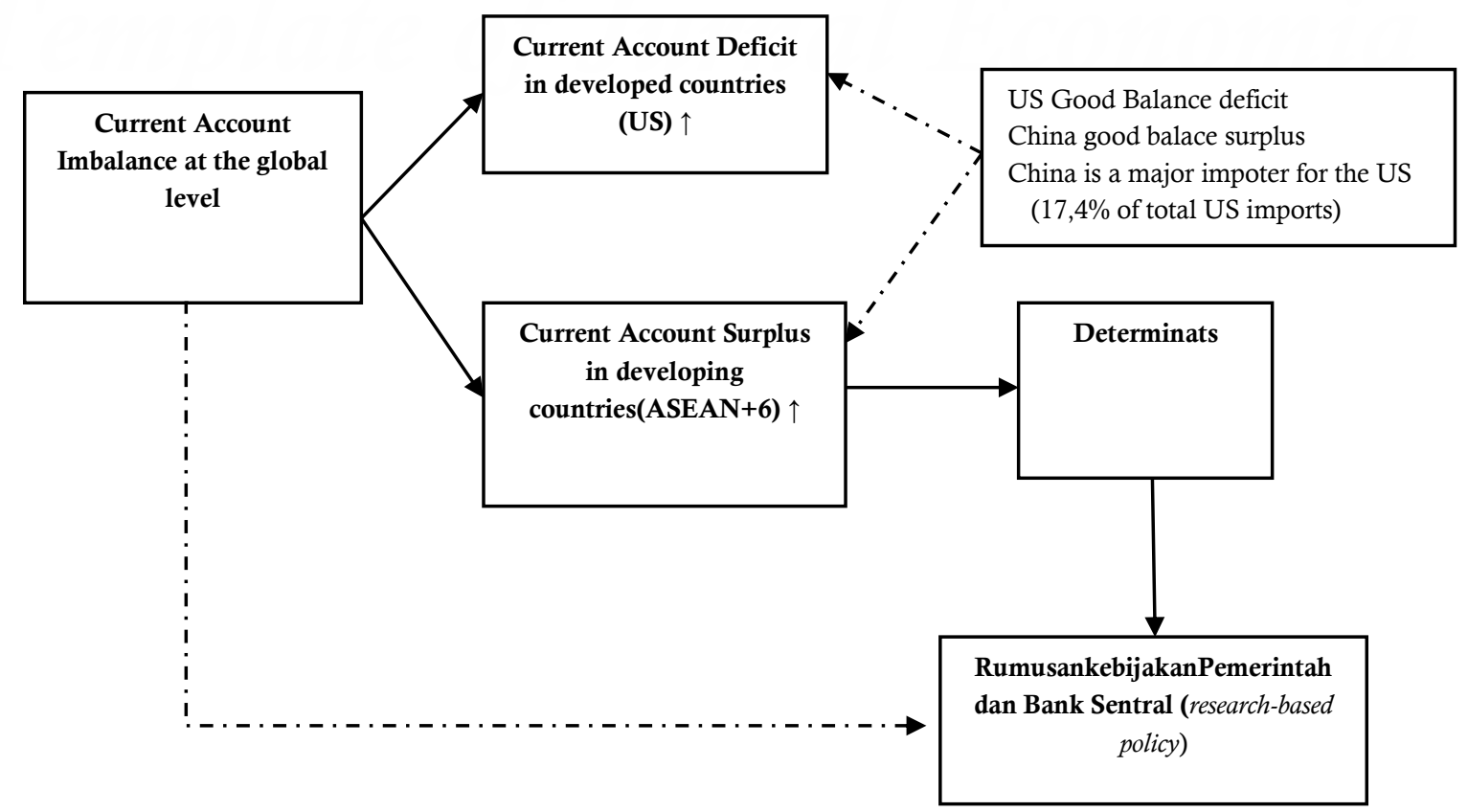

Figure 3. Current Account Imbalance

The increase in the current account surplus in ASEAN+6 is dominated by developing countries in Asia, prompted research on the determinants of the current account balance in ASEAN+6. As previously stated, the phenomenon of current account imbalance is a concern of researchers and policy makers. It is hoped that the results of this research can also be used as material for research-based policy formulations for the Government and Central Banks in the ASEAN+6 regions.

The variables that are determinants of the current account balance are explained through 3 approaches in the balance of payments. 


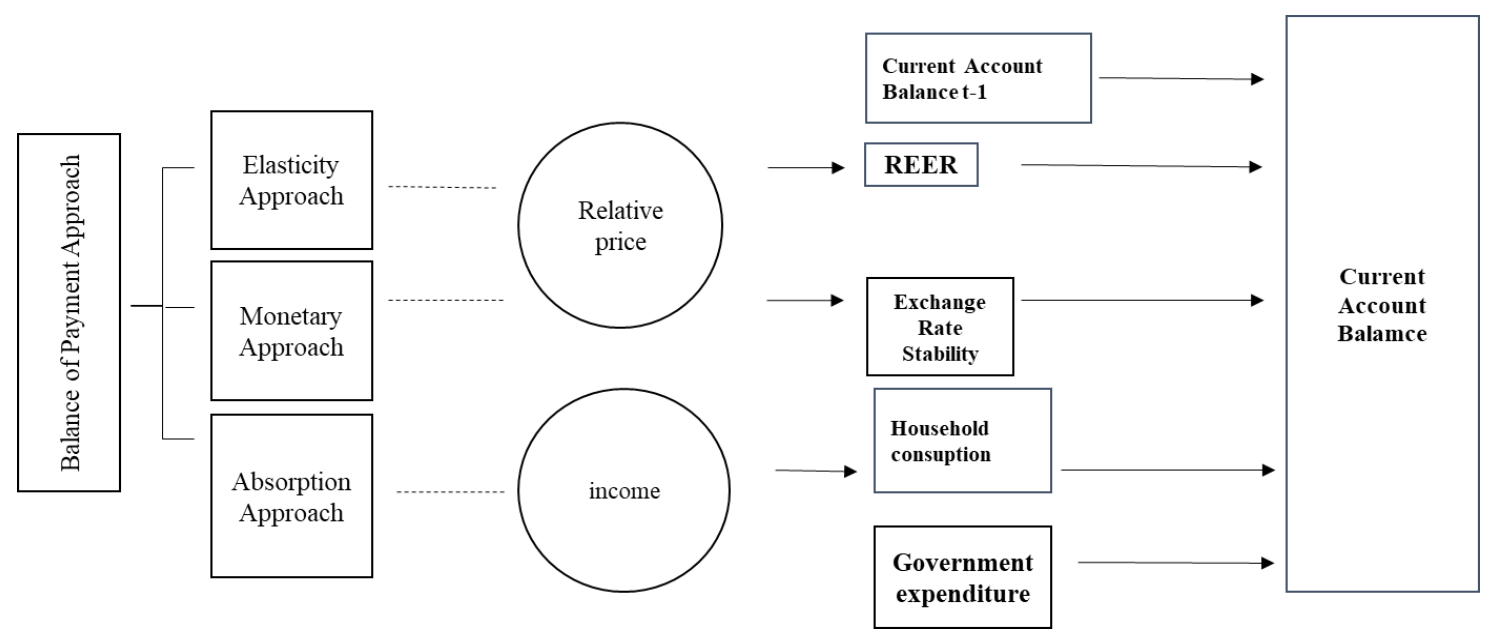

Figure 4. Balance of Payments Approach and Operation Variables

Theoretically, (Pilbeam, 2006) revealed that there are 3 approaches that explain adjustments to the balance of payments, namely the elasticity approach (Marshall-Lerner Condition), the absorption approach, and the monetary approach. The indicator of the elasticity and monetary approach is the relative price, while the absorption approach indicator is income. Each of these indicators affects the operational variables that are determinants of the current account balance. Each determinant is an instrument of each approach, namely the current account balance of the previous period (t-1), real effective exchange rate and terms of trade (elasticity approach), exchange rate stability (monetary approach), and household consumption and government spending (approach absorption).

\section{Real Effective Exchange Rate}

Theoretically, (Pilbeam, 2006) revealed that there are 3 approaches that explain adjustments to the balance of payments, namely the elasticity approach (Marshall-Lerner Condition), the absorption approach, and the monetary approach. The indicator of the elasticity and monetary approach is the relative price, while the absorption approach indicator is income. Each of these indicators affects the operational variables that are determinants of the current account balance. Each determinant is an instrument of each approach, namely the current account balance of the previous period (t-1), real effective exchange rate and terms of trade (elasticity approach), exchange rate stability (monetary approach), and household consumption and government spending (approach absorption).

\section{Terms of Trade}

Terms of Trade (ToT) is the ratio of export commodity prices to imported commodity prices (Salvatore, 2013). ToT is also interpreted as the amount of imported goods can be purchased from each unit of export goods sold. An increase in a country's ToT will be profitable since the price received from exports increases relative to the price it pays for imports. The effect of ToT on the current account can be either direct (negative effect) or indirect (positive effect). A direct effect is indicated by an increase in ToT which shows that the price of exports of goods abroad has increased with decreased competitiveness. As a result, the demand for exported goods will be decreased so that net exports (exports minus imports) as well as a country's current account balance decline. 
Thus, the increase in ToT has a negative effect on the current account balance. The indirect effect of ToT on the current account on the other hand occurs through the transmission of savings as in the theory of the Harberger-Laursen-Metzler (HLM) effect. Laursen and Metzler (1950) in (Svensson\&Razin, 1983) argue that the decrease in ToT will reduce the level of saving against a certain amount of income. The postulate of the two classic articles of Harberger and Laursen and Metzler is that the saving rate of some income will decrease as the ToT decreases. A decrease in ToT will reduce real income which in turn reduces savings. If investment is fixed and there is no change in the fiscal deficit, then the change in the saving rate is equal to the change in the current account surplus. Therefore, the HLM effect implies that the current account balance will decrease in response to a decrease in ToT. The increase in ToT indicates that the export price index which is higher than the import price index will increase real income. Assuming the tendency to consume is less than one (the increase in consumption is smaller than the increase in income), private savings will increase and have a positive impact on the current account balance (Özdamar, 2015) so that the increase in ToT has a positive effect on the current account

\section{Exchange Rate Stability}

The role of exchange rate stability is very important in achieving price and financial system stability. An unstable exchange rate will affect the price uncertainty. This uncertainty makes people unable to predict conditions that may occur in the future. In other words, the uncertainty condition makes the Rational Expectation theory unable to work. Rational Expectation is an approach that assumes that society optimally uses all available information (including current and future policies) to predict future conditions (Mankiw, 2013). Price uncertainty in the future encourages people to do things that are more certain in the present, for example by rushing to import. The accumulated increase in imports has resulted in a current account deficit.

\section{Household Consumption}

Mankiw (2016) defined consumption is the goods and services purchased by consumers. Consumption decisions are important in both long-term and short-term analysis. In the long run, consumption decisions are important given their role in economic growth while in the short term, it is important because of their role in determining the Aggregate Demand. There are several theories regarding consumption behavior. However, the most influential one is Keynesian Consumption Theory. Keynes's General Theory was published in 1936. The three assumptions in Keynes's Theory of Consumption are as follows:

Marginal Propensity to Consume (MPC) or the amount consumed from each additional dollar of income is between 0 and $1(0<\mathrm{MPC}<1)$ so that higher income will encourage higher consumption.

Average Propensity to Consume (APC) or the ratio of consumption to income, decreases when income increases are low. 
Keynes argued that income is the main determinant of consumption.

The Keynesian consumption function is written in the form:

$$
c=\bar{C}+c Y
$$

Where:

$$
\begin{aligned}
& \mathrm{C}=\text { consumption } \\
& \mathrm{Y}=\text { disposable income } \\
& \mathrm{C}^{-}=\text {is constant } \\
& \mathrm{C}=\text { MPC, which is worth } 0<\mathrm{c}<1 .
\end{aligned}
$$

In other words, an increase in income will increase consumption.

The consumption function also satisfies Keynes's second assumption as indicated by following equation:

$$
A P C=\frac{c}{Y}=\frac{c}{Y}+c
$$

When $\mathrm{Y}$ increase and $\mathrm{C}^{-} / \mathrm{Y}$ decrease, then APC or $\mathrm{C} / \mathrm{Y}$ decreases. Thus, the consumption function fulfills Keynes' third assumption, namely that current consumption is determined by current income since the interest rate is not included in the equation as a determinant of consumption.

\section{Government Expenditure}

Government spending reflects government policy. If the government has established a policy to purchase goods and services, then the government spending will reflect the costs that must be incurred by the government to implement the policy (Mangkoesoebroto, 2006). Government spending has a theoretical basis that can be seen from the identity of the balance of national income, namely $Y=C+I+G+(X-M)$. This is a source of legitimacy for the Keynesian view of the relevance of government intervention in the economy. The variable $\mathrm{Y}$ represents national income as well as reflects aggregate supply, while the right-hand side variables are called aggregate demand. The variable $G$ represents the government expenditures. The equation above shows that an increase or decrease in government spending will increase or decrease national income. There are many considerations underlie government decisions in regulating spending (Dumairy, 1996). In the modern economy, the role of government is divided into four types of role groups as follows:

The allocative role. The government in this case must plan the allocation and regulate the use of existing economic resources to make them allocated efficiently.

Distributive role. This is the role of the government in distributing resources, opportunities and economic results fairly. The government's distributive role can be pursued both through the revenue channel and through the distribution channel. On the revenue side, the government imposes taxes and collects other sources of income 
to be redistributed fairly and proportionally. In a similar pattern, the government spends its expenses.

Stabilitative role. This is the role of the government in overcoming problems that the private sector cannot solve, such as inflation, recession, or the invasion of imported goods. The government intervention has a strategic role to restore the economy.

Dynamic role. This is the role of the government in driving the economic development process in order to grow, develop and advance faster.

\section{METHOD}

Descriptive quantitative method is used to analyze the correlation between the variables observed in this study as identified in the problem to obtain empirical output that is tested statistically and economically.

The object in the research is the current account balance variable in 14 (fourteen) countries that are members of ASEAN+6 or RCEP which are influenced by the current account balance variable in the previous period (t-1), Real Effective Exchange Rate, Terms of Trade, exchange rate stability, household consumption, and government spending. The research period is from 2000 to 2017. This is the period when countries in the region attempted to restore the economy after the Asian financial crisis in 1997/1998.

The data used in this study is secondary data with annual frequency for the period 2000-2017 in 14 ASEAN+6 countries consisting of Indonesia, Malaysia, Vietnam, Thailand, Philippines, Laos, Myanmar, Cambodia, China, Japan, South Korea, India, Australia, and New Zealand. The data consists of current account balance sourced from UNCTADstat (UNCTADstat, 2019a), real effective exchange rate sourced from (Darvas, 2012), terms of trade sourced from UNCTADstat (UNCTADstat, 2019b), exchange rate stability from (Aizenman, Chinn, \& Ito, 2010), household consumption from the World Bank (The World Bank, 2018b), and government spending from the World Bank (The World Bank, 2018a). The data analysis was performed by using a dynamic data panel model with the Generalized Method of Moment method. The dynamic panel data model is illustrated as follows:

$$
y_{i, t}=\delta y_{i, t-1}+x_{i, t}^{\prime} \beta+u_{i, t} ; \mathrm{i}=1, \ldots, \mathrm{N} ; \mathrm{t}=1, \ldots, \mathrm{T} .
$$

Where $\delta$ is a scalar, $x^{\prime} I, t$ represents a matrix of size $1 \times \mathrm{K}$ and $\beta$ is a matrix of size $\mathrm{K}$ $\mathrm{x} 1$. In this case, $\mathrm{ui}, \mathrm{t}$ is assumed to follow the one way error component model as follows:

$$
u_{i t}=\mu_{i}+v_{i t} \text {. }
$$

$\mu_{-} \mathrm{i}$ is the individual effect which is assumed to be $\mu_{-} \mathrm{i} \sim \operatorname{IID}(0, \sigma 2 \mu)$ and $v_{i t}$ is the error term assumed to be $\mu_{-} \mathrm{i} \sim \operatorname{IID}(0, \sigma 2 \mathrm{v}), \mu \mathrm{i}$ and $v_{i t}$ are independent from each other (Baltagi, 2005).

An equation contains lag from the dependent variable will cause endogeneity problems. Since $y_{i, t}$ is a function of $\mu$ i. then directl $y_{i,-1}$ is also a function of $\mu$ i. The dynamic 
equation which is estimated by a static, fixed effect or random effect approach will produce a biased and inconsistent estimator (Verbeek, 2008) in (Firdaus, 2018). To solve this problem, Arellano and Bond proposed the Generalized Method of Moment (GMM) approach. There are two procedures commonly used in the GMM framework, namely the First-Difference GMM (FD-GMM) which is the Arellano-Bond approach and the GMM System which is the update carried out by Blundell and Bond. The first difference estimate was criticized for problems of bias and imprecision. To reduce this problem, Blundell and Bond (1998) suggest that when the estimator has a short period of time, an estimator that combines a system of difference estimators and an estimator at the level should be used. This is then called the GMM Blundell and Bond system. The GMM System is a system of equations that are estimated in the form of first differences and levels. Additional assumptions on the GMM system method are as follows:

$E\left(\eta_{i} \Delta y_{i 2}\right)=0$ untuk $\mathrm{i}=1, \ldots, \mathrm{N}$

The condition of the equation will hold if the mean of yit is constant for the period $1,2, .$. , $\mathrm{T}$ for every $\mathrm{i}$. The instrument matrix for the GMM system is as follows:

$Z_{i}^{*}=\left[\begin{array}{ccccc}Z_{i} & 0 & 0 & \ldots & 0 \\ 0 & \Delta y_{i 2} & 0 & \ldots & 0 \\ 0 & 0 & \Delta y_{i 3} & \ldots & 0 \\ . & . & . & \ldots & . \\ 0 & 0 & 0 & \ldots & \Delta y_{i, T-1}\end{array}\right]$

The condition of the equation will hold if the mean of yit is constant for the period $1,2, .$. , $\mathrm{T}$ for every $\mathrm{i}$. The instrument matrix for the GMM system is as follows:

$$
\boldsymbol{C A} \boldsymbol{B}_{i, t}=\boldsymbol{\alpha}+\gamma \boldsymbol{C A} B_{i, t-1}+\boldsymbol{\beta}^{\prime}[\boldsymbol{X}]_{i, t}+\eta_{i}+\varepsilon_{i, t}
$$

The condition of the equation will hold if the mean of $y_{i, t}$ is constant for the period $1,2, . ., \mathrm{T}$ for every $\mathrm{i}$. The instrument matrix for the GMM system is as follows:

$$
\begin{aligned}
& C A B_{i, t}=\beta_{0}+\beta_{1} C_{A B_{i, t-1}}+\beta_{2} \text { REER }_{i, t}++\beta_{3} \text { TOT }_{i, t}+\beta_{4} E_{\text {RS }}+ \\
& \beta_{5} \operatorname{CMPG}_{i, t}+\beta_{6} \operatorname{GOVG}_{i, t}+\varepsilon_{i, t}
\end{aligned}
$$

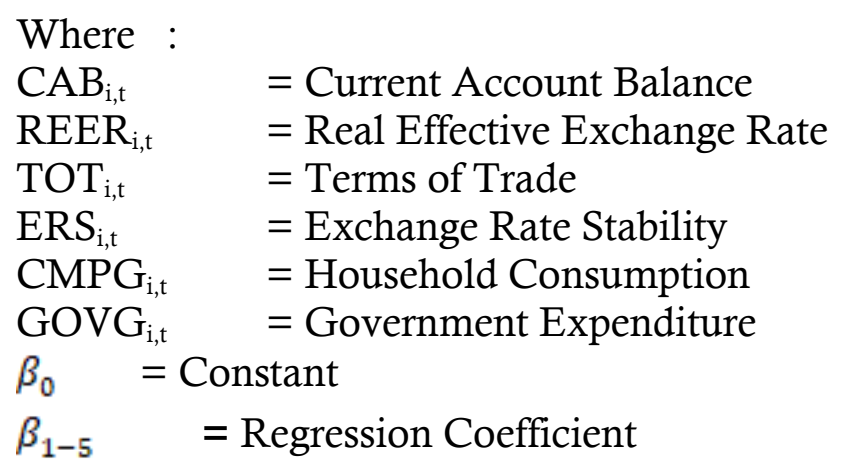


$\varepsilon_{\mathrm{i}, \mathrm{t}} \quad=$ Error term

$\mathrm{i}=1,2, ., 14=$ cross section

$\mathrm{t}=1,2, ., 18 \quad=$ time period

\section{FINDING AND DISCUSSION}

The results of dynamic panel estimation obtained using the Generalized Method of Moment (GMM) method revealed the influence of the determinants of the current account balance as in equation (6). Table 2 presents the estimation results using the GMM method, with the current account balance (CAB) (\% GDP) as the dependent variable.

Table 2. Estimation Output

\begin{tabular}{|c|c|c|c|}
\hline Variable & Coefficient & Z-stat & $p>|z|$ \\
\hline LagCurrent Account Balance $\left(\mathrm{CAB}_{\mathrm{i}, \mathrm{t}-\mathrm{l}}\right)$ & $0,7259642^{*}$ & 14,13 & 0,000 \\
\hline Real Effective Exchange Rate $\left(\mathrm{REER}_{\mathrm{i}, \mathrm{t}}\right)$ & $-0,0224178$ & $-1,31$ & 0,191 \\
\hline Terms of Trade $\left(\mathrm{TOT}_{\mathrm{i}, \mathrm{t}}\right)$ & $0,0667107^{*}$ & 5,45 & 0,000 \\
\hline Exchange Rate Stability $\left(\mathrm{ERS}_{\mathrm{i}, \mathrm{t}}\right)$ & $0,009288^{*}$ & 3,19 & 0,001 \\
\hline Household Consumption $\left(\mathrm{CMPG}_{\mathrm{i}, \mathrm{t}}\right)$ & $-0,1603844^{*}$ & $-8,53$ & 0,000 \\
\hline Government Expenditure $\left(\mathrm{GOVG}_{\mathrm{i}, \mathrm{t}}\right)$ & 0,0142495 & 0,84 & 0,401 \\
\hline $\begin{array}{l}\text { Arellano-Bond Test }\left(\mathrm{m}_{1}\right) \text { (p-value) } \\
\text { Arellano-Bond Test }\left(\mathrm{m}_{2}\right) \text { (p-value) } \\
\text { Sargan Test (p-value) }\end{array}$ & $\begin{array}{l}0,0654 \\
0,5430 \\
1,0000\end{array}$ & & \\
\hline
\end{tabular}

\section{The Effect of Current Account Lags on the Current Account in ASEAN+6}

The current account lag coefficient is positive (0.726) and the effect is significant at the $99 \%$ confidence level. This indicates that on average, a $1 \%$ increase in the current account balance for this period can provide projections in the form of an increase in TB's balance of $0.726 \%$ in the next 1 year.

The effect of the current account lag is more structural in nature and becomes a factor outside of other macroeconomic variables, which were recorded in the previous year's data. For example, the import of raw materials carried out in the previous period may be recorded again in the balance sheet for the following year, considering that the dependence on raw materials cannot be eliminated in just one year.

The positive and significant effect of the lag-current account on the current account shows the persistence of the current account, which according to Asmarani (2005), the current account balance expected in t period is a reflection of the current account balance in the previous period (t-1). This is in line with the results of research conducted by Das 
(2016), Sadiku et al (2015), Aristovnik (2008), Calderon et al (2007), and Bussiere et al (2004).

\section{The Effect of Real Effective Exchange Rate on Current Account Balance in ASEAN+6}

Based on the estimation results, the Real Effective Exchange Rate (REER) variable had no significant effect on the current account balance in ASEAN+6 countries during 2000-2017. The exchange rate is often used as a tool to increase competitiveness (encourage exports). It is also useful for improving the current account balance position. The results of this study indicated that the foreign trade policy through the exchange rate (in this case REER) in aggregate in ASEAN+6 did not affect the current account balance. In other words, neither the appreciation nor the depreciation of the exchange rate will affect the current account balance in ASEAN+6.

The insignificant effect of the REER variable on the current account balance in ASEAN +6 can also be seen from the development of REER in 14 ASEAN+6 countries during 2000-2017. Of the total 14 countries, only two countries experienced a decline in the REER index during 2000-2017, namely Japan and Malaysia. This explains that these two countries contributed to the increase in the current account balance in ASEAN+6. Meanwhile, REER conditions in 12 other countries increased during 2000-2017 which led to a decline in the current account balance. Thus, the aggregate REER has a negative effect on the current account balance, but not significant.

\section{The Effect of Terms of Trade on the Current Account Balance in ASEAN+6}

The estimation results showed that the Terms of Trade variable had a positive and significant effect on the current account balance at the $99 \%$ confidence level. A coefficient value which is 0.067 means that every 1 point increases in the Terms of Trade will increase the current account balance by $0.067 \%$. The ToT variable had a positive and significant effect on the current account balance. This is in accordance with the HarbergerLaursen-Metzler (HLM) effect theory. According to the HLM effect theory, ToT will have a positive effect on the current account balance through savings transmission. An increase in ToT which indicates that the export price index is greater than the import price index will increase real income. Assuming the tendency to consume is less than one, the increase in consumption will be smaller than the increase in income. Thus, personal savings will increase and have a positive impact on checking balances. This is in line with the results of research conducted by (Sadiku, Fetahi-Vehapi, Sadiku, \& Berisha, 2015), (Gossé\&Serranito, 2014), (Aristovnik, 2008), (Bitzis, Paleologos, \&Papazoglou, 2008), (Calderón, Chong ,\&Zanforlln, 2007), and (Chinn \& Prasad, 2003).

\section{The Effect of Exchange Rate Stability on the Current Account Balance in ASEAN+6}

Exchange rate stability variable indicated that it had a positive and significant effect on the current account balance with a confidence level of $99 \%$. With a variable coefficient of 0.009 , it points out that every $1 \%$ increase in exchange rate stability will increase the current account balance by $0.009 \%$. The positive and significant effect of exchange rate 
stability on the current account showed that a stable exchange rate was an important aspect so that ASEAN+6 countries must achieve to improve their current account balance. An unstable exchange rate, in this case, will have an impact on price uncertainty and encourage people unable to predict conditions may occur in the future as stated in the Rational Expectation theory. Rational Expectation is an approach that assumes that people use all available information optimally (including current and future policies) to predict future conditions (Mankiw, 2013). The positive and significant effect of exchange rate stability on the current account is in line with research (Das, 2016).

The positive effect of exchange rate stability on the current account balance in ASEAN+6 was also contributed by the exchange rate stability in China, Vietnam, Cambodia, and Laos, which on average had a stable exchange rate (closest to 1.0) during 2000-2017. Meanwhile, other countries in ASEAN+6 have low exchange rate stability index values on average so that the accumulation of effects is positive and significant. The positive and significant effect of exchange rate stability on the current account is in line with Das (2016) research.

\section{The Effect of Exchange Rate Stability on the Current Account Balance in ASEAN+6}

The household consumption variable had a negative and significant effect on the current account balance with a confidence level of $99 \%$. With a variable coefficient of 0.016 , it implies that every $1 \%$ increase in household consumption will decrease the current account balance by $0.016 \%$. The household consumption variable that has a negative and significant effect is in accordance with the absorption approach theory. When consumption increases, domestic absorption $(\mathrm{C}+\mathrm{I}+\mathrm{G})$ also increases. An increase in domestic absorption that is not accompanied by an increase in output (Y), it will result in a current account deficit, because the gap is closed from imports. The increase in imports had a negative impact on the trade balance as well as on the current account balance.

The negative and significant effect of household consumption on the current account balance is in line with research by Gulzar et al (2007) which have found a negative correlation between consumption variables on the current account balance in Pakistan.

\section{The Effect of Government Expenditure on the Current Account Balance in ASEAN+6}

The estimation results revealed that the Government Expenditure variable had no significant effect on the current account balance in ASEAN+6 during 2000-2017. This is different from the research of Tanner (1994) which found a negative and significant effect of government spending on the current account balance in Latin America.

Furthermore, the positive coefficient of the government expenditure variable was found to be not in accordance with the theory of absorption approach. According to the absorption approach, an increase in government spending will cause domestic absorption to be greater than domestic output and a current account deficit (the effect is negative). Based on the results of the study, it was found that government spending had a positive but not significant effect on the current account balance. The positive influence of 
government spending on the current account balance in ASEAN+6 countries is occurred when spending by the Government in ASEAN+6 countries is actually oriented to encourage exports or to suppress imports of goods and services. This positive influence can be caused by the policies taken by the governments of ASEAN+6 countries in spending their budgets, one of which is to encourage exports. For example, China, in its budgetary posture, allocates for innovation activities and high-tech product development as well as subsidies for Chinese SOEs as researched by Girma et al (2008). The study found that subsidies for SOEs in China have stimulated export activity for exporters. Other country such as India has also implemented the same thing, allocating export subsidies for the textile and machinery sector, which in 2012 reached 372 million USD (Financial Times, 2016). Thus, government spending in the two largest economies in ASEAN+6 contributes positively to government spending on the aggregate current account balance in ASEAN+6, although not significantly.

\section{Model Specification Test}

After the estimation, the model specification test was carried out, namely the Arellano-Bond test and the Sargan test. The function of Arellano-Bond test is to test the consistency of the estimates obtained from the GMM process. The consistency properties of the obtained estimators are checked from the Arellano-Bond $\mathrm{m} 1$ and $\mathrm{m} 2$ statistics. The estimator will be consistent if $\mathrm{m} 1$ shows $\mathrm{H} 0$ is rejected (p-value $<$ ) and $\mathrm{m} 2$ shows $\mathrm{H} 0$ is not rejected (p-value $>$ ) Firdaus (2018). The consistency of the estimator is shown by the results of the Arellano-Bond (AB) estimation which has a statistical value of $\mathrm{m} 1-1.8425$ which is significant at a significance level of $10 \%$ (alpha) (so H0 is rejected), and a statistical value of $\mathrm{m} 2(0.6083)$ which is not significant at significance level (alpha) $1 \%$, $5 \%$, or $10 \%$ (so $\mathrm{H} 0$ is not rejected). This indicates that the estimator is consistent without autocorrelation problems.

Firdaus (2018) suggests that the Sargan test is useful for testing the validity of the model used. If p-value $>$, then $\mathrm{H} 0$ is not rejected so that the model used is valid. The statistical value of the Sargan test of 4.6689 has a probability value of 1.0000 which is not significant at a significance level of $1 \%, 5 \%$, or $10 \%$, so that $\mathrm{H} 0$ is not rejected. In other words, it can be stated that there is no validity problem (already valid) in the model used.

\section{CONCLUSION}

This study was intended to determine the factors that affect the aggregate current account balance in ASEAN+6 countries. Knowing the estimation results of the equation model, it is concluded that in the aggregate in ASEAN+6 the current account balance is influenced by the lag-Current Account (t-1), Terms of Trade, Exchange Rate Stability, and Households Consumption variables. On the other hand, the Real Effective Exchange Rate and Government Expenditure variables have no effect on the current account balance. Based on the results of the study, the following policy implications can be formulated as follows: 
To improve the balance of the current account, export goods should not only rely on competitive prices, but also improve quality through Research and Development. High quality in this case will keep the demand for export goods stable despite rising prices.

The current account balance needs to be supported by an increase in the export portion of industries that have great potential, such as creative industries, including culinary, fashion, and handicrafts.

The government should reduce the current account deficit, among others by increasing exports of semi-finished goods that generate added value. In this case, for example, exports of raw materials such as Nickel need to be reduced to produce semi-finished goods, namely lithium batteries. This is because lithium batteries are a component in the production of electric cars in many countries.

The government needs to control imports as a source of the current deficit. In the business sector, the policy that can still be continued is import substitution by replacing imported materials with domestic production. For example, the B-20 policy (mixing 20\% palm oil into a mixture of diesel fuel) needs to be implemented in all business sectors in order to improve the oil and gas trade balance. Meanwhile, in the household sector, import control can be carried out by continuing to impose income tax rates $(\mathrm{PPh})$ on the consumption of imported goods, such as electronic goods.

\section{REFERENCES}

Aizenman, J., Chinn, M., \& Ito, H. (2010). The Trilemma Indexes. Retrieved February 5, 2019, from http://web.pdx.edu/ ito/trilemma_indexes.htm

Aristovnik, A. (2008). Short-Term Determinants of Current Account Deficits: Evidence from Eastern Europe and the Former Soviet Union. Eastern European Economics, 46(1), 24-42. https://doi.org/10.2753/eee0012-8775460102

Baltagi, B. H. (2005). Econometric Analysis of Panel Data (Third). West Sussex: John Wiley \& Sons Ltd.

Bitzis, G., Paleologos, J. M., \& Papazoglou, C. (2008). The Determinants of the Greek Current Account Deficit: The EMU Experience. Journal of International and Global Economic Studies, 1(1), 105-122. Retrieved from https://pdfs.semanticscholar.org/80da/728a33ce79e23d68e7cbaa8136b22524929d.p df

Calderón, C., Chong, A., \& Zanforlln, L. (2007). Current Account Deficits in Africa: Stylized Facts and Basic Determinants. Economic Development and Cultural Change, 56(1), 191-221. https://doi.org/10.1086/520557

Chinn, M. D., \& Prasad, E. S. (2003). Medium-term Determinants of Current Accounts in 
Industrial and Developing Countries: An Empirical Exploration. Journal of International Economics, 59(1), 47-76. https://doi.org/10.1016/S0022-1996(02)000892

Darvas, Z. (2012). Real Effective Exchange Rates for 178 Countries: a New Database. Retrieved from Bruegel website: https://bruegel.org/publications/datasets/realeffective-exchange-rates-for-178-countries-a-new-database/

Das, D. K. (2016). Determinants of Current Account Imbalance in The Global Economy: a Dynamic Panel Analysis. Journal of Economic Structures, 5(1). https://doi.org/10.1186/s40008-016-0039-6

Ditjenppi. (2018). RCEP. Retrieved August 17, 2019, from http://ditjenppi.kemendag.go.id/index.php/berita/detail/ia-cepa-momentum-barukemitraan-indonesia-australia

Dumairy. (1996). Perekonomian Indonesia. Jakarta: Erlangga.

Financial Times. (2016). China eliminates subsidies for its exporters _ Financial Times. Retrieved December 6, 2019, from https://www.ft.com/content/4f4d1240-024a$11 \mathrm{e} 6-99 \mathrm{cb}-83242733 \mathrm{f} 755$

Firdaus, M. (2018). Aplikasi Ekonometrika Untuk Data Panel Dan Time Series Data. Bogor: IPB Press.

Gossé, J. B., \& Serranito, F. (2014). Long-run Determinants of Current Accounts in OECD Countries: Lessons for Intra-European Imbalances. Economic Modelling, 38, 451-462. https://doi.org/10.1016/j.econmod.2014.01.008

Mangkoesoebroto, G. (2006). Ekonomi Publik (Edisi 3). Yogyakarta: BPPE.

Mankiw, N. G. (2013). Macroeconomics (eight). New York: Worth Publisher.

Özdamar, G. (2015). Factors Affecting Current Account Balance of Turkey: a Survey With the Cointegrating Regression Analysis. Pressacademia, 4(4), 633-633. https://doi.org/10.17261/pressacademia.2015414533

Pilbeam, K. (2006). International Finance (Third). New York: PALGRAVE MACMILLAN.

Sadiku, L., Fetahi-Vehapi, M., Sadiku, M., \& Berisha, N. (2015). The Persistence and Determinants of Current Account Deficit of FYROM: An Empirical Analysis. Procedia Economics and Finance, 33(15), 90-102. https://doi.org/10.1016/s22125671(15)01696-2

Salvatore, D. (2013). International Economics. In Journal of Chemical Information and Modeling (11th ed, Vol. 53). https://doi.org/10.1017/CBO9781107415324.004 
Svensson, L. E. O., \& Razin, A. (1983). The Terms of Trade and the Current Account: The Harberger-Laursen-Metzler Effect. Journal of Political Economy, 91(1), 97-125. https://doi.org/10.1086/261130

The world bank. (2018a). General government final consumption expenditure. https://doi.org/10.1787/9789264075108-table11_1-en

The world bank. (2018b). Households and NPISHs Final consumption expenditure. Retrieved October 30, 2019, from The World Bank website: https://data.worldbank.org/indicator/NE.CON.PRVT.CD?year_high_desc=true

UNCTADstat. (2019a). Current Account Balance. Retrieved February 5, 2019, from https://unctadstat.unctad.org/wds/TableViewer/tableView.aspx

UNCTADstat. (2019b). Terms of Trade. Retrieved February 5, 2019, from https://unctadstat.unctad.org/wds/TableViewer/tableView.aspx

Uneze, E., \& Ekor, M. (2012). The Determinants of Current Account Balance in an OilRich Exporting Country: the Case of Nigeria. OPEC Energy Review, 36(4), 456-478. https://doi.org/10.1111/j.1753-0237.2012.00221.x

Universitas Gadjah Mada. (2016). Nilai Tukar - Macroeconomic Dashboard. Retrieved February 5, 2019, from https://macroeconomicdashboard.feb.ugm.ac.id/nilai-tukar/

Yang, L. (2011). An Empirical Analysis of Current Account Determinants in Emerging Asian Economies (No. E2011/10). 